\title{
WAS THE HIGH PLAINS A PINE-SPRUCE FOREST?
}

\author{
Stephen A. Hall
}

\section{Introduction}

Twenty thousand years ago a sheet of ice more than a mile thick mantled the Northern Plains, the Midwest, and most of Canada. The ice sheet, called the Laurentide, was the last of several Ice Age glaciers that plowed through the north (Fig. 1). The cold climate that spawned the ice sheet also changed the distribution of plants and animals everywhere in the world. Ecologists speculated that the Great Plains prairies may have disappeared entirely, replaced by forests.

Far from the ice sheet, the Llano Estacado or High Plains of

\section{ICE AGE TIME SCALE}

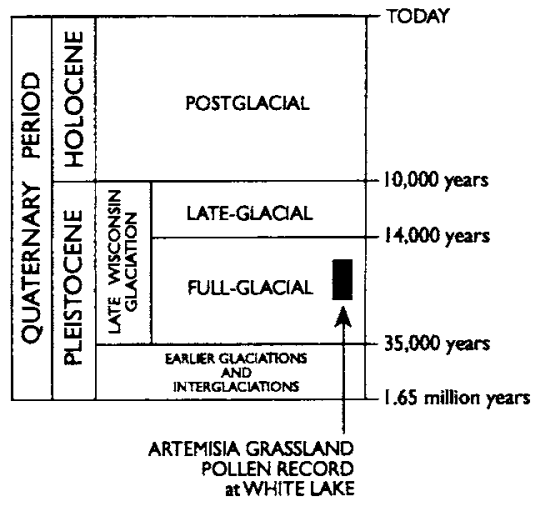

Fig. 1. Time scale of the Quaternary Period or Ice Age extending back 1.65 million years; the Laurentide ice sheet reached its maximum about 18,000 to 20,000 years ago.

Texas and eastern New Mexico was home to a dozen species of giant horses and bison, all extinct today and known only from their fossilized bones. Looking at their teeth, which are little different from the teeth of their modern descendants, we know that these extinct animals were grazers. It almost goes without saying that grazers and grasslands go together, yet for many years, despite the evidence from fossil Ice Age horses and bison, ecologists have believed that the High Plains was not rangeland but instead was a forest composed of pine and spruce trees.

In the 1950s and 1960s, the Ice Age history of North America was of special interest to ecologists because of the dramatic changes that had taken place. During the period of cooler glacial climate that prevailed over the continent, plant and animal communities in the north were displaced hundreds of miles by the Laurentide ice sheet (Fig. 2). While early ideas suggested wholesale southward movement of more-or-less intact forests, it was soon realized that Ice Age plant communities were very different from those that we see today. Now it is also recognized that, during periods of environmental change and stress, plant and animal species alike migrate independently of each other, not in groups or associations. As a consequence, the make-up of today's modern plant communities and biomes may have come about only recently.

Most of our information on Ice Age plant biogeography comes from studying fossil pollen grains in peat bogs and lakes. Plants produce tremendous amounts of pollen. In the High Plains grasslands, range plants produce more than 120 billion pollen grains per acre every year (Hall 1990). Some pollen grains fall in playa lakes where they are entombed in mud. By recovering fossil pollen that was deposited thousands of years ago, it is possible to tell what plants were growing in the vicinity and what range conditions were like.

Between 1957 and 1959, an innovative project was sponsored by the Museum of New Mexico, Santa Fe, to determine the environmental history of the southern High Plains. Geologists examined sand dunes and playa lakes, and paleontologists studied fossil bones and snails and even fossilized remains of algae from the lake muds left behind in the Ice Age playas. During the project, studies of fossil pollen from the ancient and now-dry playas turned out to be of unexpected importance, destined to be cited for decades to come.

\section{"Pine-Spruce Forest"}

The lake muds contained high percentages of pine and spruce pollen. The ecologist who studied the pollen stated, "the most probable interpretation of the high pine pollen values...is that the pine formed an open forest with a very scanty field vegetation" (Hafsten 1961, p. 84, his emphasis). In a later paper, he interpreted it as "a cold and wet period with open boreal woodlands of pine and spruce..." (Hafsten 1964, p. 414).

Although the interpretation of a "pine-spruce forest" on the High Plains had been accepted by scientists and range specialists, the original work left two unanswered questions.

1. The high percentages of pine pollen in the lake muds were too high; some of the mud contained 85 to $100 \%$ pine. Modern pine forests generally produce only $60 \%$ pine pollen, the remaining $40 \%$ represented by other trees, understory shrubs, and ground plants. The ecologist was aware of this, and worried about the lack of pollen from herbs, stating simply that there was "...a very poor field vegetation covering the Southern High Plains" (Hafsten 1961, p. 85).

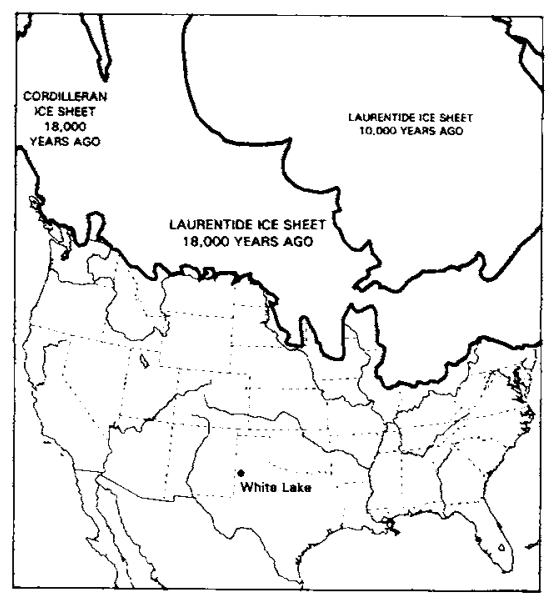

Fig. 2. Location of Ice Age playa deposits at White Lake, Texas, in relation to the Laurentide ice sheet. 


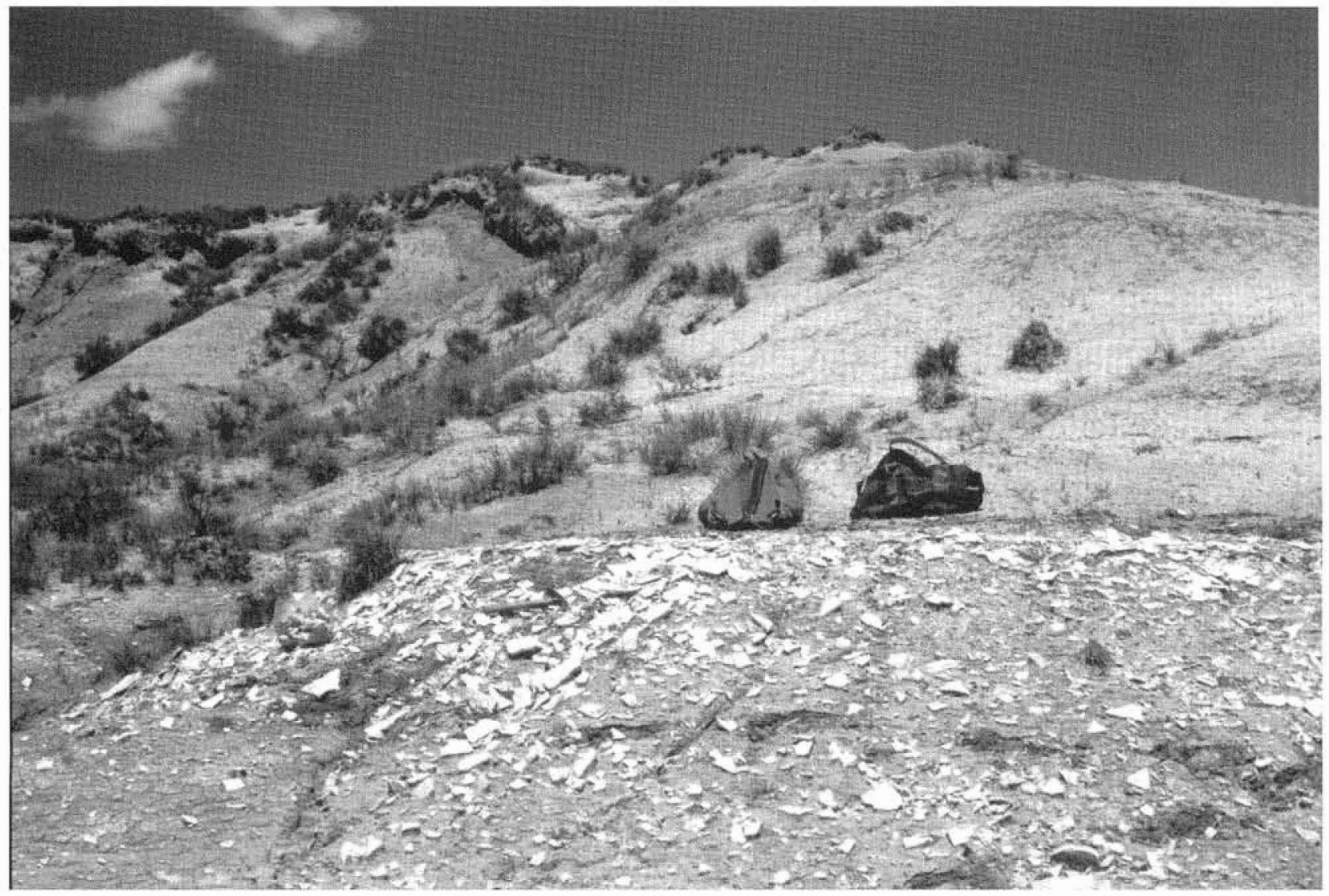

Fig. 3. Ice Age lake muds, White Lake, Muleshoe National Wildlife Refuge, Bailey Co., Texas; the top of the ridge is the crest of a lee dune (photo, S. A. Hall).

2. The project ecologist also worried about the effects of a conifer forest on soil development on the Llano Estacado. Pine forests produce podzolic soils, very different from prairie soils, and none of the forest soils were present on the High Plains. Citing studies from temperate Europe, he stated that dry-climate adapted pines may thrive on very weak soils along with low pollen-producing forms, such as lichen and ericaceous shrubs in pine-barrens. If the weak soils were eroded by winds, he states, it would account for the absence of a conifer-forest soil. He also states that "It may be that the buried soil beds discovered in a few places represents the only remains of former soil profiles, for instance, the buried soil of the Judkins red sand" [near Monahans, Texas] (Hafsten 1961, p. 84). More recently, the absence of podzol soils has been reiterated as evidence that there was no conifer forest on the Llano Estacado. (Holliday 1987).

\section{Ice Age Sagebrush Grasslands}

A new pollen study has produced a novel twist to the old data and calls for a revision of the status of the "pine-spruce forest." Reinvestigation of pollen from White Lake at Muleshoe National Wildlife Refuge, Bailey Co., Texas (Fig. 3 ), has revealed that the upper part of the glacial-age playa clays is dominated by very high percentages of pine pollen, just as were accurately reported earlier. However, not realized by earlier workers, the high percentages of pine pollen are a product of differential pollen preservation and are useless for interpreting vegetation.
The cause of differential preservation can be explained by pollen-grain chemistry. The wax-like pollen walls have a composition that varies from one plant species to another. Because of the differences in pollen chemistry, pollen grains from some plants are more susceptible to deterioration than are others. During weathering of pollen-bearing sediments, some pollen types are lost first while other types "survive" and are the last to go. Pine and spruce pollen fall into the latter category. When non-pine pollen is destroyed, the percentages of pine pollen go up. So, when the glacial-age playa lakes on the Llano Estacado dried up 14,000 years ago, the lake muds weathered and the pollen became partly destroyed, leaving behind a zone of high percentages of pine and spruce in the upper part of the old lake deposits.

Fortunately, the lower part of the lake muds were not weathered and contain lots of well-preserved pollen. Pollen from unweathered mud indicates that the glacial-age vegetation of the High Plains was a sagebrush grassland and not a pine-spruce forest after all (Hall and Valastro 1995).

Now that it is apparent that a sagebrush grassland was present on the High Plains during the Ice Age, other ecological records begin to fall into place, showing that a grassland vegetation once dominated the southern Great Plains and throughout much of the now-arid southwest, from Kansas to Arizona (Fredlund 1995; Hall 1985, 1997). 


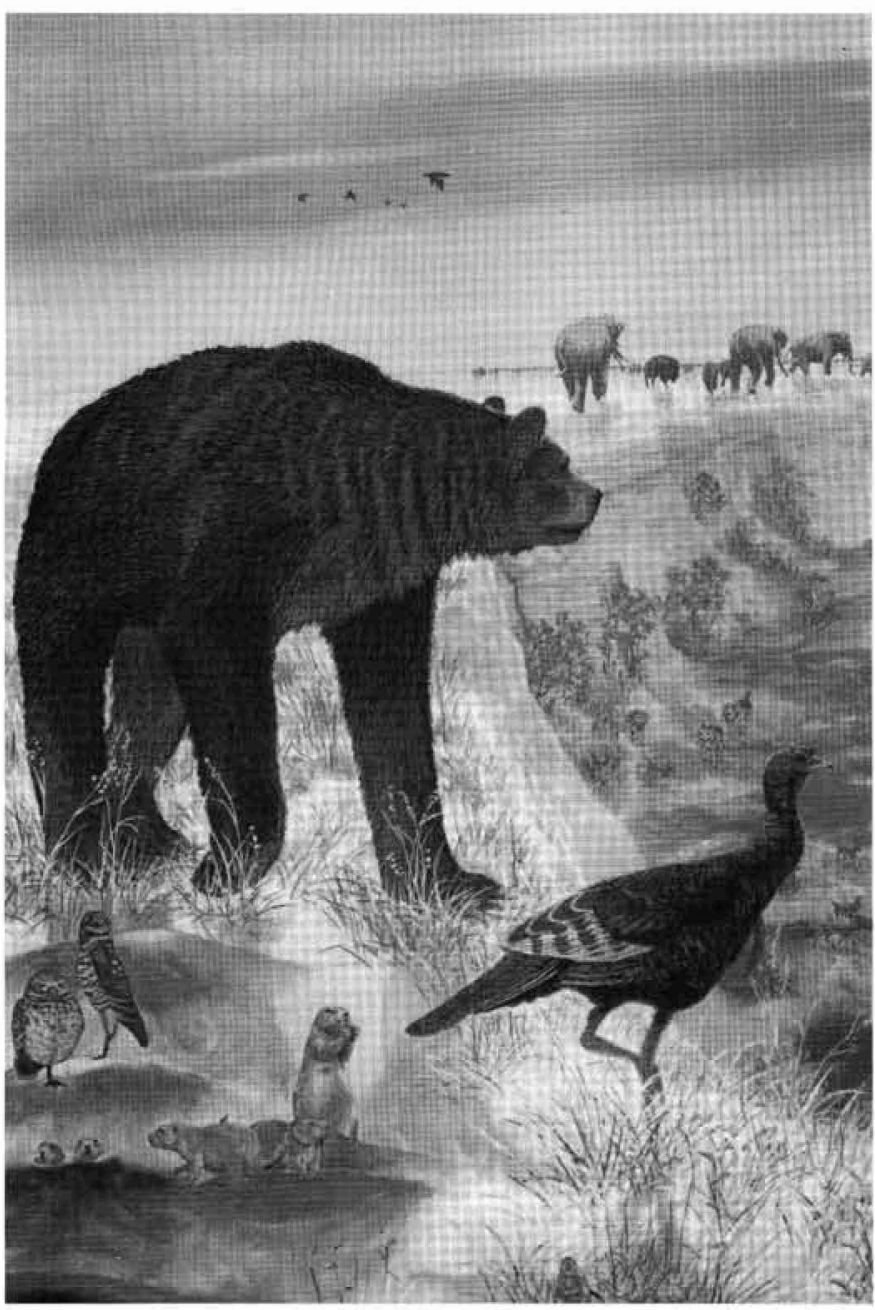

Fig. 4. Painting of the Texas High Plains during late-glacial time about 12,000 years ago; although sagebrush is not shown in the painting, it was a major component of the vegetation 18,000 years ago (painting by Nola Davis, courtesy of Texas Parks and Wildlife, Interpretation and Exhibits Branch).

\section{Conclusion}

The southern High Plains was a sagebrush grassland during the last glaciation 16,000 to 20,000 years ago, and, even though the climate was cooler than today, there was no pinespruce forest. The sagebrush grassland was part of a larger Ice Age biome that extended throughout the south-central region of the continent and included mammoths, bison, horses, camels, and other extinct mammals (Fig. 4). The Ice Age grasslands may have been very different in species composition and abundance from that seen in modern prairies. The vertebrate fauna and climate were clearly different from those of today. Nevertheless, the extensive Ice Age sagebrush grassland was the predecessor from which the modern prairies and desert grasslands have been derived.

\section{Supporting Literature}

Fredlund, G. G. 1995. Late Quaternary pollen record from Cheyenne Bottoms, Kansas. Quaternary Research 43:67-79.

Hafsten, U. 1961. Pleistocene development of vegetation and climate in the southern High Plains as evidenced by pollen analysis. In Paleoecology of the Llano Estacado, F. Wendorf, ed., 59-91, Fort Burgwin Research Center, Publ. No. 1, Santa Fe, N.M.: Museum of New Mexico Press.

Hafsten, U. 1964. A standard pollen diagram for the southern High Plains, USA, covering the period back to the early Wisconsin glaciation. International Quaternary Congress, VI, Report 2, 407-420, Warsaw.

Hall, S. A. 1985. Quaternary pollen analysis and vegetational history of the Southwest. In Pollen Records of Late-Quaternary North American Sediments, V. M. Bryant, Jr. and R. G. Holloway, eds., 95-123, Dallas: American Association of Stratigraphic Palynologists Foundation.

Hall, S. A. 1990. Pollen deposition and vegetation in the southern Rocky Mountains and southwest Plains, USA. Grana 29:47-61.

Hall, S. A. 1997. Pollen analysis and woodrat middens: Re-evaluation of Quaternary vegetational history in the American Southwest. Southwestern Geographer 1:25-43.

Hall, S. A., and S. Valastro, Jr. 1995. Grassland vegetation in the southern Great Plains during the Iast glacial maximum. Quaternary Research 44:237-245.

Holliday, V. T. 1987. A reexamination of Late-Pleistocene boreal forest reconstructions for the southern High Plains. Quaternary Research 28:238-244.

Acknowledgment

The writer thanks Don Clapp (Muleshoe National Wildlife Refuge) for permission to work on the refuge, and Cathryn A. Hoyt (Texas A \& M University) for editorial comments. The Late Pleistocene painting by Nola Davis (courtesy of Texas Parks and Wildlife, Interpretation and Exhibits Branch) was created for the Lubbock Lake Landmark State Historical Site, Lubbock. Texas; their permission to use the painting is greatly appreciated.

The author is with the Department of Geography, University of Texas at Austin, Austin, Texas 78712 